\title{
Comparative Analysis Of Small Medium Enterprise Profitability Based On Its Ownership Form And Ethnicity: Study On Automotive Sector In Yogyakarta
}

\section{Arif Singapurwoko*}

\section{Abstract}

Tujuan penelitian ini adalab untuk mengetabui apakah terdapat perbedaan operating profit margin, netprofit margin dan return on investment antara pengusaba Jawa dengan Tionghoa, dan bentuk sole proprietorship dengan partnership. Lokasi penelitian dilakukan di Yogyakarta pada perusabaan-perusaban skala kecil dan menengab yang bergerak dalam bisnis otomotif suku cadang mobil dan bengkel.

Variabel independent dalam penelitian ini adalab operating profit margin, net.profit margin dan return on investment, sedangkan tingkat keuntungan yang diperoleh merupakan variabel dependen. Setiap populasi diambil sampelnya untuk membandingkan net profit margin dan return on investment. Sampel penelitian dibagi menjadi dua kelompok yaitu berdasarkan bentuk kepemilikan dan etnis. Kepemilikan dibagi menjadi dua bentuk, yaitu sole proprietorship dan partnership. Etnis pemilik dibagi menjadi dua, yaitu Jawa dan Tionghoa.

Uji Statistik yang digunakan adalab independent sample t-test karena data yang digunakan berdistribus normal. Hasil penelitian menjelaskan babwa terdapat perbedaan yang signifikan antara pengusaba Jawa dengan Tionghoa pada operating profit margin, net profit margin, dan return on investment. Temuan lainya adalab bentuk sole proprietorship dengan bentuk partnership memiliki perbedaan yang signifikan pada operatingprofit margin, netprofit margin, and return on investment.

Keywords : small medium enterprise, sole proprietorship and partnership, net profit margin, return on investment.

Dosen Fakultas Ekonomi UII 


\section{Introduction}

The global crisis in 2008 has driven the developing countries to be more precautious in investing in securities. The developing countries does not intended for their economy to be influenced by securities. The investment in real sector is prioritized to strengthen the fundamental of a country. Based on World Bank data, see figure 1, SME has significantly contributed to employment and gross domestic products (GDP). Therefore, every developing country's government attempt to develop SME through several ways such as training, funding for free or in the form of loan, and others. Onugu (2005) explained SMEs have played and continue to play significant roles in the growth, development and industrialization of many economies the world over. Fadhil (2010) explained SMEs have been very important in many countries including Malaysia because of its role for the country" $s$ economic growth.

\section{Figure 1}

\section{SME Contribution to Employment and GDP}

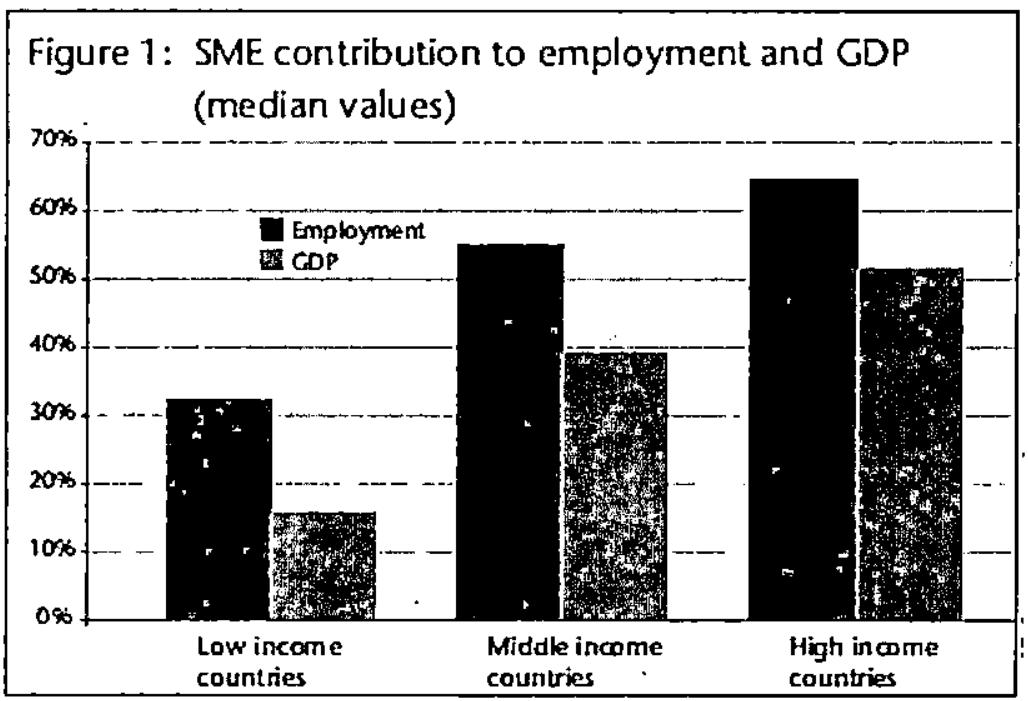

Source: World Bank, 2011.

Indonesia government play a major enroll in developing $\mathrm{SME}$ in Indonesia to building strong and firm national economy. The government role is to encourage the private sector together in SME activity. This can be seen by the increasing number of financial organization such as bank and non-bank in providing loan to the society in running SME business. The government also encourages the educational institution in developing and creating human resources that are ready to be an entrepreneur. The fact that in the past three years Indonesian economy has developed positively, and manages to be in the 
third rank after China and India. Other than that, in table 1 describe the growth of SME' in Indonesia. These data indicate the increase in number of SME from. year to year, and it was predicted that this year it reached more than 20 million SME.

Table 1

Total SME in Indonesia

\begin{tabular}{|c|c|c|c|}
\hline YEAR & $\mathbf{2 0 0 2}$ & $\mathbf{2 0 0 3}$ & $\mathbf{2 0 0 4}$ \\
\hline TOTAL & 15.703 .560 & 15.784 .059 & 17.145 .244 \\
\hline
\end{tabular}

Source: Central of Statistic Body. 2002-2004

The problem or topic that is raised in this research is about the opinion in the Indonesian society collected from several printed media which explained that Javanese entrepreneur cannot compete against Chinese entrepreneur in business. This research will discover the profitability of Javanese entrepreneur and Chinese entrepreneur or its descendant whether there is differences or not in their SME business. If not, it can be concluded that Javanese entrepreneur able to compete in obtaining the same profitability with the Chinese entrepreneur in SME business. This can reject the society's opinion that the profitability of Javanese entrepreneur in all this time cannot compete with Chinese entrepreneur.

Moreover, this research will compare the SME's profitability between proprietorship and partnership. This research is done to describe whether the SME with partnership is better in providing profit than proprietorship. The previous research done by Onugu (2005) stated that there is a significant difference of SME in the form of partnership which has greater profit than proprietorship. In Indonesia, SME in the form of partnership is more than proprietorship; therefore this research will support the previous research. The researcher motivation in doing this research is that SME is the trending topic in Indonesia.

\section{Problem Identification}

Based on the explanation above, in this research there are several questions that should be discussed, such as:

1. Are there any significant difference in profitability between SME . of Javanese entrepreneur and Chinese entrepreneur?

2. Which has better average profitability between Javanese entrepreneur and Chinese entrepreneur?

3. Are there any significant difference in profitability between SME in the form of proprietorship and partnership? 
4. Which has better average profitability between SME in the form of proprietorship and partnership?

\section{Literature Review}

\section{Small Medium Enterprise}

Turan dan Urkmez (2010) explained that different countries have different SME definition; however the important consideration is the number of employee, asset, and income. In Indonesia, the definition of SME based on Act Number 20/2008 is the enterprise in the form of sole proprietorship and partnership with the total assets of $\mathrm{Rp} 50$ million - Rp 10 billion, annual income of $\mathrm{Rp} 50$ million - $\mathrm{Rp} 50$ billion, and maximum number of employees is 300 people. Radam et al (2008) explained An enterprise is considered as an SME based on the annual sales turnover or number of full-time employees. An SME in the manufacturing sector is defined as an enterprise with full-time employees not exceeding 150 employees or with annual turnover not exceeding RM25 million. According to Small and Medium Industries Development Corporation (SMDEC), SME is defined as the enterprise that with full time workers less than 75 employees or the share holder's capital is no-more than M \$ 2.5 million. Based on SMIDEC, SME defined into two, which are:

a. Small Industry (SI), with the number of employee of 5-50 people or the share capital with no more than M \$ 500 thousand.

b. 2. Medium Industry (MI), with the number of employee of 50-75 people or the share capital between $\mathrm{M} \$ 500$ thousand $-\mathrm{M} \$ 2.5$ million.

Based on Word Bank, SME is classified into two referring groups:

a. Medium Enterprise:

- Maximum number of employees is 300 people

- Maximum annual income is $\$ 15$ million

- Maximum number of assets is $\$ 15$ million

b. Small Enterprise:

- Maximum number of employees is 30 people

- Maximum annual income is $\$ 3$ million

- Maximum number of assets is $\$ 3$ million

\section{Sole Proprietorship and Partnership}

Sole proprietorship is a business or enterprise that owned and managed by one person and bares all the responsibility and risk. While partnership is the relationship between two or more people and they agree to share profits and risks that attached on their business (Onugu, 2005). The advantages of each type of ownership are as follows: 
a Sole Proprietorship : Easy to form and wind up, direct motivation, quick decision and prompt action, better control, maintenance of business secrets,. close personal relation, flexibility in operation, encourage self-employment.

b. Partnership: Easy to form, availability of large resources, better decisions, flexibility in operations, sharing risks, protection of interest of each partner, benefits of specialization.

\section{Ethnicity}

Suryadarma et al (2006) describe ethnicity as the fundamental factor in the human society where culture, language, religion, behavior, and biological traits affect behavior or way of working. Indonesia comprise of many ethnics, Suryana et al (2006) research found that four ethnics dominate income and population in Indonesia, which are Javanese, Malay, Bugis, and Chinese. Butler and Herring (1991) explained that ethnic migrants group has better possibility to run a business than local ethnic. In this research the local ethnic group is Javanese as the Chinese as the ethnic migrants. Javanese ethnic is the majority population that lives in Java island, while Chinese is the people that came from China and stayed in Indonesia or born in Indonesia and has descendant from Chinese.

\section{Financial Performance}

Several researcher uses profitability as the performance measurement in determining the good and bad SME. The previous research has been done by Hudson et al. (2001), Onugu (2005), Ntalakas et al. (2006), and Locke (2006). Hudson et al. (2001) uses cash flow, market share, overhead cost reduction, inventory performance, cost control, sales profitability, efficiency, and product cost reduction as the financial performance. According to them, sales profitability and market share is the best measurement in determining SME performance. Onugu (2005) argues that his research uses operating profit margin as the best way to measure profit because it does not consider whether the SME uses debt or capital in financing the business. Ntalakas et al. (2006) stated that the best measurement is to refer to Balance Scorecard. In financial perspective, the best measurement is return on investment. Locke (2006) also stated the return on investment with net profit margin, debt ratio, and inventory turnover is the best combination to measure financial performance of SME.

\section{Net Profit Margin}

Brigham and Houston (2004) described that net profit margin indicates the level of the company's ability generate profit in every sales value. The higher the net profit margin, the better the company in generating profit. This 
ratio is suitable in SME because the main income of SME is the product sales or services. The net profit margin formula is as follow;

\section{Operating Profit Margin}

$$
\text { Net Profit Margin }=\frac{\text { Earning After Tax }}{\text { Sales }}
$$

Brigham and Houston (2004) described that operating profit margin is a tool to measure the company's ability to generate profit where it uses income before interest and tax. This ratio is suitable to determine the SME ability evenly regardless the company capitalize it using debt or without debt. The operating profit margin formula is as follow:

$$
\text { Operating Profit Margin }=\frac{\text { Operating Income }}{\text { Total Sales }}
$$

\section{Return on Investment}

The profitability ratio as a proxy of financial performance is widely used in several researches. The increase in profitability ratio indicates the company success in implementing the company's strategy and method by relating it with the profit gained from sales and investment (Van Horne and Wachowicz, 2005). The return on investment calculation is as follow:

$$
\text { Return on Investment }=\frac{\text { Earning After Tax }}{\text { Total Asset }}
$$

\section{Previous Researches And Hypothesis Development}

There has no research found in Indonesia on SME financial performance, therefore the result of this research refer to research on other countries. However, the overseas research is limited in number. Locke (2006) research compares the SME financial performance of companies located in the city with the rural area. The result indicates that there is a significant difference between SME in the city and in the rural area. Also the SME's financial performance in average in the city is better than in the rural area. Onugu (2005) research result indicates that SME in the form of partnership has better performance than SME in the form of sole proprietorship and both has significant differences. A classic research done by Butler and Herning (1991) described that ethnic migrants has bigger possibility to be a good entrepreneur than the local ethnic group.

Based on the previous researches, it can be hypothesized as follow:

H1 : There is a significant difference in net profit margin of SME owned by Javanese with Chinese

H2 : There is a significant difference in operating profit margin of SME owned by Javanese with Chinese 
H3 : There is a significant difference in return on investment of SME owned . by Javanese with Chinese

H4 : There is a significant difference in net profit margin of SME in the form of sole proprietorship with partnership

H5 : There is a significant difference in operating profit margin of SME in the form of sole proprietorship with partnership

H6 : There is a significant difference in return on investment of SME in the form of sole proprietorship with partnership

\section{Research Methodology}

\section{Data Collection}

This research uses SME located in Yogyakarta and run in automotive sector which is in selling spare parts and services as the population. The reason in deciding Yogyakarta as the research location is because the majority of business is dominated with SME and the accessibility of acquiring direct data sample. The automotive sector is selected because in average this business sector has perform for more than three years, grow fast, the availability of data, and the simplicity in acquiring samples. Based on the survey, the population of automotive sector is $345 \mathrm{SME}$. The data used is sales, earning before interest and tax, net profit, and investment in 2010 to calculate operating profit margin, net profit margin, and return on investment. The sampling method uses purposive sampling method with several sampling criteria as follow:

a.' Javanese entrepreneur : the business owner is Javanese, where the total population is $113 \mathrm{SME}$ and the sample is $50 \mathrm{SME}$.

b. Chinese entrepreneur : the business owner is Chinese, where the total population is $232 \mathrm{SME}$ and the sample is $50 \mathrm{SME}$.

c., Sole proprietorship $:$ the business owner is one person, where the total population is 272 SME and the sample is 50 SME.

d. Partnership : the business owner is more than one person, where the total population is $73 \mathrm{SME}$ and the sample is 50 SME.

\section{1.) Analysis Method}

\section{Normality Test for Data}

Normality test is used to test whether the data used in the research are normally distributed or not. The explanation of normal data distribution is that the data follow the normal distribution curve where the data converge to mean and median. The normality test for data in this research uses Kolmogrov Sminov, to test the two directions by comparing the probability (p) acquired that have significant level $(\alpha)$ of $5 \%$. If the $p$ value $>\alpha$ then the data can be 
considered to be normally distributed and if $p$ value $>\alpha$ then the data are not normally distributed.

\section{Hypothesis Testing}

If the normality test is conducted and the result of the data test shows that the data are normally distributed, then the next step is to use parametric test which is independent sample t-test. Locke (2006) uses independent sample t-test to compare the SME financial performance in the city with the rural area. The steps of hypothesis testing are as follow :

a. Determine the statistic hypothesis for each research variables

H1 : SME Javanese entrepreneur - NPM $\neq$ SME Chinese Entrepreneur NPM

H2 : SME Javanese entrepreneur - OPM $\neq$ SME Chinese Entrepreneur OPM

H3 : SME Javanese entrepreneur - ROI $\neq$ SME Chinese Entrepreneur - ROI

H4 : SME Sole Proprietorship-NPM $\neq$ SME partnership - NPM

H5 : SME Sole Proprietorship-OPM $\neq$ SME partnership - OPM

H6 : SME Sole Proprietorship-ROI $\neq$ SME partnership - ROI

b. Select the level of significance $\alpha=5 \%$ and determine the degree of freedom from the sample

c. Determine the significant value

d. Interpret: if the significant value is $<\alpha=5 \%$, then Ho is rejected. In contrary if the significant value is $>\alpha=5 \%$, then Ho is accepted.

\section{The Result Of Hypothesis Testing}

\section{Normality Test}

The purpose of normality test is to test whether the data is normally distributed or not. In testing the data normality, this research uses kolmogorov smirnov test. The decision to determine whether to use parametric or nonparametric test is based on the probability value. The decision is determined if the probability value $>0.05$, then it fulfill the normality assumption. The result of normality test using kolmogorov smirnov test is as follow: 
Arif Singapurwoko, Comparative Analysis Of Small Medium Enterprise........

Table 2.

The Result of Normality Test With Kolmogorov Smirnov Test

\begin{tabular}{|l|c|c|c|}
\hline \multicolumn{1}{|c|}{ Variabel } & Sig. & Sig. Value & Remarks \\
\hline SME JAVA - NPM & 0,578 & 0,05 & Normal \\
SME CHINA - NPM & 0,397 & 0,05 & Normal \\
SME JAVA - OPM & 0,255 & 0,05 & Normal \\
SME CHINA - OPM & 0,446 & 0,05 & Normal \\
SME JAVA - ROI & 0,318 & 0,05 & Normal \\
SME CHINA - ROI & 0,391 & 0,05 & Normal \\
SME SOLE - NPM & 0,447 & 0,05 & Normal \\
SME PARTNER - NPM & 0,229 & 0,05 & Normal \\
SME SOLE - OPM & 0,179 & 0,05 & Normal \\
SME PARTNER - OPM & 0,372 & 0,05 & Normal \\
SME SOLE - ROI & 0,301 & 0,05 & Normal \\
SME PARTNER - ROI - & 0,155 & 0,05 & Normal \\
\hline
\end{tabular}

Source: Processed Data.

Based on the normality test in table 2, the kolmogorov smirnov test above indicates that the probability value for every SME's profitability $>0.05$. This result indicates that all data are normally distributed, therefore the next test used is independent sample t-test.

\section{3: Hypothesis Testing}

The result summary of hypothesis one to three statistic test can be seen in táble 3. The summary for each hypothesis is as follow:

- H1 : Accepted, the significant value $<\alpha=5 \%$, therefore there is a significant difference in net profit margin between SME of Javanese entrepreneur and SME of Chinese entrepreneur. The average value of Chinese entrepreneur is greater than Javanese entrepreneur. This indicates that Chinese entrepreneur able to generate higher net profit margin than Javanese entrepreneur.

- H2 : Accepted, the significant value $<\alpha=5 \%$, therefore there is a significant difference in operating profit margin between SME of Javanese entrepreneur and SME of Chinese entrepreneur. The average value of Chinese entrepreneur is greater than Javanese entrepreneur. This indicates that Chinese entrepreneur able to generate higher operating profit margin than Javanese entrepreneur.

- H3 : Accepted, the significant value $<\alpha=5 \%$, therefore there is a significant difference in return on investment between SME of - 
Javanese entrepreneur and SME of Chinese entrepreneur. The average value of Chinese entrepreneur is greater than Javanese entrepreneur. This indicates that Chinese entrepreneur able to generate higher return on investment than Javanese entrepreneur.

Table 3 : Result Summary of Independent Sample T-Test NPM, OPM, and ROI Between SME of Javanese Entrepreneur and Chinese Entrepreneur

\begin{tabular}{|c|c|c|c|c|c|}
\hline $\begin{array}{c}\text { Profitability } \\
\text { Variables }\end{array}$ & \multicolumn{2}{|c|}{$\begin{array}{c}\text { SME் of Javanese } \\
\text { Entrepreneur }\end{array}$} & \multicolumn{2}{c|}{$\begin{array}{c}\text { SME of Chinese } \\
\text { Entrepreneur }\end{array}$} & \multirow{2}{*}{ 2-tail Sig. } \\
\cline { 2 - 5 } & Mean & $\begin{array}{c}\text { Standard } \\
\text { Deviation }\end{array}$ & Mean & $\begin{array}{c}\text { Standard } \\
\text { Deviation }\end{array}$ & \\
\hline NPM & 0,3299 & 0,15107 & 0,7618 & 0,19062 & 0,000 \\
\hline OPM & 0,2748 & 0,14914 & 0,6702 & 0,15953 & 0,000 \\
\hline ROI & 0,3718 & 0,13227 & 0,7861 & 0,18739 & 0,000 \\
\hline
\end{tabular}

Source: Processed Data

The result summary of hypothesis four to six statistic test can be seen in table 4. The summary of each hypothesis as follows:

- H4 : Accepted, the significant value $<\alpha=5 \%$, therefore there is a significant difference in net profit margin between sole proprietorship. SME form and partnership SME form. The average value of partnership SME form is greater than sole proprietorship SME form. This indicates that partnership SME form able to generate higher net profit margin than sole proprietorship SME form.

- H5 : Accepted, the significant value $<\alpha=5 \%$, therefore there is a significant difference in operating profit margin between sole proprietorship SME form and partnership SME form. The average value of partnership SME form is greater than sole proprietorship SME form. This indicates that partnership SME form able to generate higher operating profit margin than sole proprietorship SME form.

- H6 : Accepted, the significant value $<\alpha=5 \%$, therefore there is a significant difference in return on investment between sole proprietorship SME form and partnership SME form. The average value of partnership SME form is greater than sole proprietorship SME form. This indicates that partnership SME form able to generate higher return on investment than sole proprietorship SME form. 
Table 4 : Result Summary of Independent Sample T-Test NPM, OPM, and ROI Between Sole Proprietorship SME form and Partnership SME form :

\begin{tabular}{|c|c|c|c|c|c|}
\hline \multirow{2}{*}{$\begin{array}{l}\text { Profitability } \\
\text { Variables: }\end{array}$} & \multicolumn{2}{|c|}{$\begin{array}{l}\text { Sole Proprietorship } \\
\text { SME form }\end{array}$} & \multicolumn{2}{|c|}{ Partnership SME form } & \multirow{2}{*}{ 2-tail Sig } \\
\hline & Mean & $\begin{array}{l}\text { Standard } \\
\text { Deviation }\end{array}$ & Mean & $\begin{array}{l}\text { Standard } \\
\text { Deviation }\end{array}$ & \\
\hline NPM & 0,2726 & 0,13478 & 0,8320 & 0,2054 & 0,000 \\
\hline OPM & 0,2273 & 0,13926 & 0,8179 & 0,1857 & 0,000 \\
\hline ROI & 0,2591 & 0,13552 & 0,8815 & 0,2182 & 0,000 \\
\hline
\end{tabular}

Source: Processed Data

\section{Conclusions}

This research result provides an answer to several questions in problem formulation that there is a significant difference in profitability between Javanese entrepreneur- and Chinese entrepreneur. The Chinese entrepreneur generates better profit than Javanese entrepreneur. Other research results indicates that there is a significant difference in profitability between sole proprietorship SME form and partnership SME form. Partnership SME form is better than sole proprietorship SME form because they generate higher profit than sole proprietorship SME form. The recommendation for the future research is' to add other financial measures other than profitability to have better insight than only viewed from profitability only. 


\section{References}

Brigham, E.F. dan J.F. Houston. 2004. Fundamentals of Financial Management, 10th edition. Singapore, Thomson South-Western.

Butler, J.S. and Herring, C. 1991: "Ethnicity And Etrepreneurship In America". Sociological Perspectives. 34(1), p.79-94

Fadhil, N.F.M. 2010. "Managing Company's Financial Among Small and Medium Non-Manufacturing Companies". Far East Journal of Psychology and Business. 2(1), p.17-36

Hudson, M., Smart, A., and Bourne, M. 2001. "Theory and practice in SME performance measurement systems". International Journal of Operations \& Production Management.

Locke, S. 2006. "Regional Development Policy and Small Medium Enterprise Financial Performance". Australasian Journal of Regional Studies. 12(2), p.191-204.

Ntalakas, G., Mihiotis, A., and Mylonakis, J. 2006. "Business Performance Measurement Frameworks and SMEs". International Bulletin of Business Administration. p.42-47. Eurojournals, Inc.

Onugu, B.A.N. 2005. "Small Medium Enterprises in Nigeria: Problems and Prospects". Dissertation. St. Clement University.

Radam, A., Abu, M.L., and Abdullah, A.M. 2008. "Technical Efficiency of Small and Medium Enterprise in Malaysia: A Stochastic Frontier Production Model". International Journal of Economics and Management. 2(2). p. 395-408.

Suryadarma, D., Widyanti, W., Suryahadi, A., andSumarto, S. 2006. "From Access to Income and Ethnic Inequality in Indonesia". SMERU Working Paper. SMERU Research Institute.

Turan, A.H. dan Urkmez, T. 2010. "Information Technology Satisfaction of Small and Medium Sized Enterprises in Turkey". International Bulletin of Business Administration. 9(1). p.43-55. Eurojournals, Inc.

Van Horne, J.C dan Wachowicz, J.M. 2005. Fundamentals of Financial Management. Jakarta, Salemba Empat.

www.bps.go.id

www.nos.org

www.smecorp.gov.my

www.worldbank.org 